\title{
Efekty ekonomiczne z zastosowania napędów asynchronicznych w modernizowanym tramwaju typu $105 \mathrm{Na}(805 \mathrm{Na})$
}

\author{
Przedmiotem artykulu jest wyszczególnienie informacji dotyczacych korzyści ekonomicz- \\ nych wynikajacych ze stosowania energoelektronicznych napędów asynchronicznych. \\ Uwzględniono informacje zwiazane z wykorzystaniem standardowego uktadu z silnikami \\ pradu przemiennego oraz $w$ wariant $z$ zasobnikiem energii hamowania.
}

Aktualnie w Polsce eksploatowanych jest 3669 (31-12-2008 r.) tramwajów różnych typów. Aż 85,3\% tych pojazdów ma standardowy napęd $\mathrm{z}$ zastosowaniem silników szeregowo - bocznikowych prądu stałego. Na przełomie wieków zaczęły w Polsce pojawiać się tramwaje $\mathrm{z}$ napędami opartymi na nowoczesnych układach energoelektronicznych, w I fazie z wykorzystaniem napędów impulsowych (chopper) i wkrótce po nich $\mathrm{z}$ napędami układu prądu przemiennego $\mathrm{z}$ wykorzystaniem silników asynchronicznych.

W dobie gospodarki rynkowej szczególnie duże znaczenie ma ekonomiczny aspekt rozwiązań technicznych. Wraz z rozwojem gospodarki ocena poszczególnych rozwiązań technicznych i ich przydatności do zastosowań praktycznych zaczęła przesuwać się $\mathrm{z}$ pozycji kosztu inwestycji w kierunku LCC (koszt życia) rozwiązania.

Mając powyższe na uwadze w roku 2005 Zakład Elektroniki Przemysłowej ENIKA wprowadził na rynek asynchroniczny układ napędowy do tramwaju dedykowany do modernizacji najpowszechniejszego tramwaju w Polsce $105 \mathrm{Na}$ i pokrewnych. Układ był w pełni przystosowany do montażu $\mathrm{w}$ standardowym nadwoziu bez konieczności jego modernizacji. Wykorzystano również silniki, które zostały zaprojektowane w sposób umożliwiający ich montaż w gnieździe silnika DC.

Wyniki eksploatacyjne - uzyskane w badaniach wykonanych $\mathrm{w}$ warunkach rzeczywistych, uzyskane dzięki uprzejmości dyrekcji MPK w Poznaniu oraz Tramwajów Elbląskich przedstawiają bardzo zbliżone rezultaty. Średnie zużycie energii w tramwaju z układem klasycznym - rezystorowym wynosi nie mniej niż 2,1 kWh/km (2,6 kWh/km dla MPK-Poznań) na jeden wagon typu $105 \mathrm{Na}$. W tramwaju z napędem ENIKI zużycie energii zamyka się liczbą 1,7 $\mathrm{kWh} . / \mathrm{km}$. Daje to niebagatelną oszczędność zużycia energii na poziomie 19\%. Na tę oszczędność składa się szereg przyczyn. Do głównych z nich należą:
- brak strat na rezystorach w fazie rozruchu

- wyższa sprawność silników asynchronicznych ( o około $5 \%$ )

- ograniczenie strat na rezystorach w fazie hamowania ze względu na oddawanie energii do sieci.

- zastosowanie przetwornicy statycznej, której sprawność znacznie przekracza sprawność przetwornicy elektromechanicznej

Dodatkowo oprócz oszczędności związanych bezpośrednio ze zużyciem energii elektrycznej pojawia się szereg czynników ograniczających koszty. Należą do nich miedzy innymi:

- ograniczenie liczby aparatów stykowych, co bezpośrednio wpływa na zmniejszenie wydatków na materiały eksploatacyjne (komory gaszeniowe, styki, połączenia podatne), oraz $\mathrm{z}$ racji wyeliminowania maszyn komutatorowych zbędne stały się szczotki grafitowe.

- ograniczenie nakładów na pracę bezpośrednią przy utrzymaniu urządzeń elektromechanicznych - przeglądy i obsługa eksploatacyjna styczników i maszyn komutatorowych

Ważnym czynnikiem wpływającym na wynik ekonomiczny przewoźnika jest również poziom utraconych korzyści. Wynikają one $\mathrm{z}$ awarii pojazdów, które uniemożliwiają ich pracę liniową, niekiedy wymuszając wyłączenie $\mathrm{z}$ tej pracy sprawnego składu niezbędnego do holowania uszkodzonego tramwaju.

Mniejsza awaryjność układów energoelektronicznych $\mathrm{w}$ porównaniu $\mathrm{z}$ układami elektromechanicznymi skutkuje również lepszą oceną transportu publicznego i to zarówno tą pozaekonomiczną, kształ- 
towaną przez pasażerów i w mediach, jak i przeliczaną na złotówki przez zarządy transportu w rozliczaniu kursów niewykonanych i niepunktualnych.

Bardzo ważnym czynnikiem ekonomicznym ściśle związanym $\mathrm{z}$ niezawodnością tramwajów jest wskaźnik wykorzystania taboru. W wagonach klasycznych oprócz styczników i silników DC funkcjonowały takie aparaty jak rozrusznik, przekaźnik samoczynnego rozruchu czy regulator napięcia baterii akumulatorów. Są to aparaty o skomplikowanej budowie i wymagające częstych przeglądów i regulacji. Jakiekolwiek zaniedbania w ich obsłudze skutkowały zjazdami awaryjnymi, co wymuszało utrzymywanie potężnej rezerwy wagonowej. W celu utrzymania komunikacji na przyzwoitym poziomie, nawet do 30 $\%$ liczby wagonów jeżdżących w ramach rozkładu jazdy musiało stać w gotowości do wyjazdu na linię na wypadek zjazdu awaryjnego.

Doświadczenia z eksploatacji wagonów z napędem asynchronicznym wykazują, że realne jest prowadzenie pracy przewozowej na przyzwoitym poziomie nawet ze wskaźnikiem wykorzystania na poziomie 0,9 . Oznacza to możliwość redukcji liczby pojazdów, co wprost przekłada się na ograniczenie niezbędnych środków finansowych na zakupy nowego taboru. Gdybyśmy pokusili się o analizę sytuacji zajezdni w której stacjonuje 100 pojazdów, zgodnie z założeniami zwiększenie wskaźnika wykorzystania taboru z 0,7 do 0,9 pozwala na zmniejszenie stanu inwentarzowego do 80 wagonów. Przy założeniu ceny wieloprzegubowego wagonu zastępującego dwa wagony $105 \mathrm{Na}$ na poziomie $7000000 \mathrm{zł}$ daje to kwotę 140000000 zł. Przeznaczenie części tej kwoty na modernizację napędów wagonowych pozwala na szybkie zwiększenie niezawodności taboru i przyśpieszenie wymiany najstarszych wagonów na nowe. Oczywiście przy decyzjach indywidualnych muszą być brane pod uwagę zarówno planowane środki inwestycyjne, oraz wiek i stan taboru.

Wraz z przybywaniem liczby wagonów wyposażonych w system zwrotu energii hamowania do sieci mażemy spodziewać się ograniczeni efektu oszczędności energii elektrycznej. Przy założeniu zachowania niezmienności liczby pojazdów na odcinku sieci w miarę przyrostu liczby wagonów $\mathrm{z}$ napędem asynchronicznym obserwujemy wzrost podaży energii rekuperacyjnej, przy jednoczesnym spadku energochłonności pojazdów. Prowadzi to wprost do zmniejszenia prawdopodobieństwa, że energia hamowania jednego tramwaju zostanie wykorzystana przez inny będący w fazie rozruchu. Prowadzi to w rezultacie do wytracania energii w rezystorach.

Powyższe tendencje spowodowały podjęcie $\mathrm{W}$ ZEP ENIKA Sp. z o. o. prac nad wykonaniem projektu i prototypu układu napędu asynchronicznego zasobnikowego dla tramwaju. Istotą innowacji tego projektu jest gromadzenie energii odzyskanej w trakcie hamowania elektrodynamicznego w baterii wysokopojemnych kondensatorów i wykorzystywanie jej w fazie najbliższego rozruchu. Obliczenia teoretyczne oraz wyniki podobnych badań prezentowane w Japanese Railway Engineering Nr 156/2006 wskazują, że układ jest w stanie zgromadzić ponad $70 \%$ energii kinetycznej pojazdu. Rozwój technologii wytwarzania takich kondensatorów sprawił, że cena umożliwia już wykorzystanie ich w sposób uzasadniony ekonomicznie. Przewagą układu z zasobnikiem nad standardowym napędem asynchronicznym jest gwarancja wykorzystania energii odzyskowej. Dodatkowych oszczędności można upatrywać $\mathrm{w}$ fakcie obniżenia mocy szczytowej pobieranej z podstacji, za co zakłady energetyczne pobierają dodatkowe opłaty.

Przed operatorem transportu publicznego pojawi się konieczność określenia parametrów układu. Energia hamownia tramwaju jest uzależniona od konfiguracji trasy, napełnienia wagonu i prędkości początkowej. W poniższej tabeli zawarto poziom energii hamowania $\mathrm{w}$ zależności od masy i prędkości początkowej wagonu.

\section{Energia hamowania wagonu $105 \mathrm{Na}$}

Tabela 1

\begin{tabular}{|c|c|c|c|c|c|}
\hline & & \multicolumn{3}{|c|}{ Masa pojazdu } & \\
\hline & & Pusty & $\begin{array}{c}\text { Średnio } \\
\text { napełniony }\end{array}$ & Pełny & \\
\hline \multirow{3}{*}{$\begin{array}{l}0 \\
0 \\
0 \\
0 \\
0 \\
0 \\
0 \\
0\end{array}$} & $30 \mathrm{~km} / \mathrm{h}$ & 0,49 & 0,63 & 0,755 & \multirow{3}{*}{ 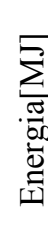 } \\
\hline & $50 \mathrm{~km} / \mathrm{h}$ & 1,38 & 1,75 & 2,11 & \\
\hline & $70 \mathrm{~km} / \mathrm{h}$ & 2,69 & 3,4 & 4,11 & \\
\hline
\end{tabular}

Koszt inwestycji w zasobnik kondensatorów w aktualnych cenach można szacować na poziomie 50 tys. zł za zdolność do akumulowania $1 \mathrm{MJ}$ energii.

$\mathrm{Z}$ analizy projektowej wynika, że zarówno bateria superkondensatorów jak i dodatkowy, towarzyszący jej układ energoelektroniczny zmieszczą się w wolnych przestrzeniach na dachu i pod podłogą wagonu.

Czynnikiem sprzyjającym proponowanym rozwiązaniom jest perspektywa forsowania przez decydentów polityki nastawionej na rozwiązania energooszczędne. Wcześniej czy później można również spodziewać się przerzucenia na konsumentów energii kosztów emisji $\mathrm{CO}_{2}$ do środowiska. 